\title{
Two Coryneform Bacteria Isolated from the Surface of French Gruyère and Beaufort Cheeses Are New Species of the Genus Brachybacterium: Brachybacterium alimentarium sp. nov. and Brachybacterium tyrofermentans sp. nov. $\dagger$
}

\author{
KARIN SCHUBERT, ${ }^{1 *}$ WOLFGANG LUDWIG ${ }^{2}$ NINA SPRINGER,${ }^{2}$ REINER MICHAEL KROPPENSTEDT, ${ }^{3}$ \\ JEAN-PIERRE ACCOLAS, ${ }^{4}$ AND FRANZ FIEDLER ${ }^{1}$ \\ Institut für Genetik und Mikrobiologie der Universität München, 80638 Munich, ${ }^{1}$ Lehrstuhl für Mikrobiologie, \\ Technische Universität München, 80290 Munich, ${ }^{2}$ and DSM-Deutsche Sammlung von \\ Mikroorganismen und Zellkulturen GmbH, 38124 Braunschweig, ${ }^{3}$ Germany, and \\ Station de Recherches Laitières, Institut National de la Recherche \\ Agronomique, 78352 Jouy-en-Josas Cedex, France ${ }^{4}$
}

\begin{abstract}
New species names, Brachybacterium alimentarium and Brachybacterium tyrofermentans, are proposed for two coryneform bacteria isolated from the surfaces of Gruyère and Beaufort cheeses. These two species are similar in their biochemical and chemotaxonomic characteristics but distinct from previously described bacteria. The most distinctive characteristics are the presence of meso-diaminopimelic acid-containing peptidoglycan with a D-Glu-D-Asp interpeptide bridge and the presence of erythritol teichoic acids that contain diaminoglucuronic acid (an uncommon substituent). The menaquinone pattern of these organisms is unique among coryneform bacteria. DNA-DNA hybridization experiments revealed that the level of hybridization between the two organisms is $15 \%$, which indicates that they are distinct species. Despite the unique biochemical characteristics of these bacteria, a 16S rRNA sequence comparison revealed that they are unquestionably related to Brachybacterium faecium, Brachybacterium nesterenkovii, and Brachybacterium conglomeratum. DNA-DNA hybridization experiments performed with these three species, B. alimentarium, and B. tyrofermentans revealed that the levels of complementarity ranged from 11 to $38 \%$, values that are similar to the values obtained for Brachybacterium strains described previously. With the inclusion of $B$. alimentarium and $B$. tyrofermentans the genus Brachybacterium becomes somewhat heterogeneous with respect to chemotaxonomic characteristics.
\end{abstract}

Accolas et al. (2) described the isolation of a number of highly salt-tolerant ( 15 to $20 \% \mathrm{NaCl}$ ) coryneform bacteria from the surfaces of Gruyère and Beaufort cheeses. All of these organisms grew best at temperatures between 20 and $30^{\circ} \mathrm{C}$. Most were able to hydrolyze gelatin but not starch and could not decompose uric acid. Deamination of arginine did not occur or occurred only after 1 month (1).

The cell walls of two of the isolates were particularly interesting. These cell walls contained a peptidoglycan type not found in any previously described bacteria and also contained an uncommon erythritol teichoic acid (24). The novel features of these isolates, designated strains CNRZ $925^{\mathrm{T}}(\mathrm{T}=$ type strain) and CNRZ 926 ${ }^{\mathrm{T}}$, made their taxonomic position interesting. The peptidoglycan type of strains CNRZ $925^{\mathrm{T}}$ and CNRZ $926^{\mathrm{T}}$ is the meso-diaminopimelic acid-D-Asp-D-Glu type and resembles the meso-diaminopimelic acid-(D-Glu $)_{2}$ type found in members of the genus Brachybacterium $(6,11)$.

We studied a number of taxonomic characteristics of strains CNRZ $925^{\mathrm{T}}$ and CNRZ $926^{\mathrm{T}}$ and compared these organisms with strains belonging to the genus Brachybacterium.

\section{MATERIALS AND METHODS}

Bacterial strains and culture conditions. Strains CNRZ $925^{\mathrm{T}}$ and CNRZ $926^{\mathrm{T}}$ were obtained from the Centre National de Recherches Zootechniques (CNRZ), Jouy-en-Josas, France. Reference strain Brachybacterium conglomeratum NCIMB

* Corresponding author. Mailing address: Institut für Genetik und Mikrobiologie der Universität München, Maria-Ward-Strasse 1a, 80638 Munich, Germany. Phone: (089) 179198 77. Fax: (089) 17919849.

$\dagger$ We dedicate this publication to Prof. Dr. Otto Kandler on the occasion of his 75 th birthday.
9859 was obtained from the National Collection of Industrial and Marine Bacteria (NCIMB), Aberdeen, United Kingdom, and reference strains B. conglomeratum CCM 2136 and Brachybacterium nesterenkovii CCM 2432 were obtained from the Czechoslovak Collection of Microorganisms (CCM), Brno, Czech Republic. Brachybacterium faecium DSM $4810^{\mathrm{T}}$, B. nesterenkovii DSM $9573^{\mathrm{T}}$, Arthrobacter globiformis DSM $20124^{\mathrm{T}}$, and Dermabacter hominis DSM $7083^{\mathrm{T}}$ were obtained from the DSM-Deutsche Sammlung von Mikroorganismen und Zellkulturen (DSM), Braunschweig, Germany.

The strains were grown aerobically at $30^{\circ} \mathrm{C}$ in a medium containing (per liter) $10 \mathrm{~g}$ of tryptone, $5 \mathrm{~g}$ of yeast extract, $5 \mathrm{~g}$ of glucose, and $5 \mathrm{~g}$ of $\mathrm{NaCl}(\mathrm{pH} \mathrm{7.2)}$; strains CNRZ $925^{\mathrm{T}}$ and CNRZ $926^{\mathrm{T}}$ were also grown in a medium containing (per liter) $17 \mathrm{~g}$ of tryptose, $3 \mathrm{~g}$ of soy peptone, $5 \mathrm{~g}$ of yeast extract, $2.5 \mathrm{~g}$ of glucose, $5 \mathrm{~g}$ of $\mathrm{NaCl}, 2.5 \mathrm{~g}$ of $\mathrm{KH}_{2} \mathrm{PO}_{4}$, and $1 \mathrm{ml}$ of Tween $80(\mathrm{pH} \mathrm{7.3)}$. For solid media $12 \mathrm{~g}$ of agar per liter was added.

Morphological and biochemical properties. Cell morphology was studied by using cultures grown for 16 and $48 \mathrm{~h}$. Growth at different $\mathrm{pH}$ values and temperatures was examined by using $\mathrm{pH}$ values of 5.5 to 9 and temperatures of 20 to $42^{\circ} \mathrm{C}$; these experiments were performed in $100-\mathrm{ml}$ Erlenmeyer flasks with integrated cuvettes. Optical density at $580 \mathrm{~nm}$ was determined with a Milton Roy spectrophotometer.

Utilization of sugars, tyrosine, and xanthine, $\mathrm{NO}_{3}{ }^{-}$and $\mathrm{NO}_{2}{ }^{-}$reduction, and hydrolysis of casein, starch, and gelatin were studied by using the methods of Seiler et al. (25).

Utilization of each of the 20 naturally occurring amino acids (100 mg/liter) was determined on MOPS (morpholinepropanesulfonic acid) medium (21) supplemented with (per liter) $40 \mathrm{mg}$ of adenosine, $40 \mathrm{mg}$ of guanosine, $40 \mathrm{mg}$ of cytidine, $40 \mathrm{mg}$ of thymidine, $40 \mathrm{mg}$ of uridine, $0.1 \mathrm{mg}$ of vitamin $\mathrm{B}_{\mathrm{t} 2}, 0.1 \mathrm{mg}$ of $p$-aminobenzoic acid, $2 \mathrm{mg}$ of biotin, $2 \mathrm{mg}$ of folic acid, $5 \mathrm{mg}$ of riboflavine, $5 \mathrm{mg}$ of pantothenic acid, $5 \mathrm{mg}$ of lipoic acid, and $10 \mathrm{mg}$ of pyridoxine- $\mathrm{HCl}$. Decreases in the concentrations of single amino acids were determined with an amino acid analyzer (Biotronic, Maintal, Germany).

Production of indole and ammonification were determined by using a medium containing $40 \mathrm{~g}$ of peptone per liter. The presence of liberated $\mathrm{NH}_{3}$ was determined with Nessler's reagent, and the presence of indole was determined with Kovács reagent. Lecithinase activity and tellurite reduction were examined by using a medium containing (per liter) $5 \mathrm{~g}$ of meat extract, $10 \mathrm{~g}$ of casein peptone, $1 \mathrm{~g}$ of yeast extract, $10 \mathrm{~g}$ of sodium pyruvate, $12 \mathrm{~g}$ of glycine, $5 \mathrm{~g}$ of lithium chloride and $15 \mathrm{~g}$ of agar ( $\mathrm{pH} 6.8$ ) to which $50 \mathrm{ml}$ of egg yolk emulsion per liter 

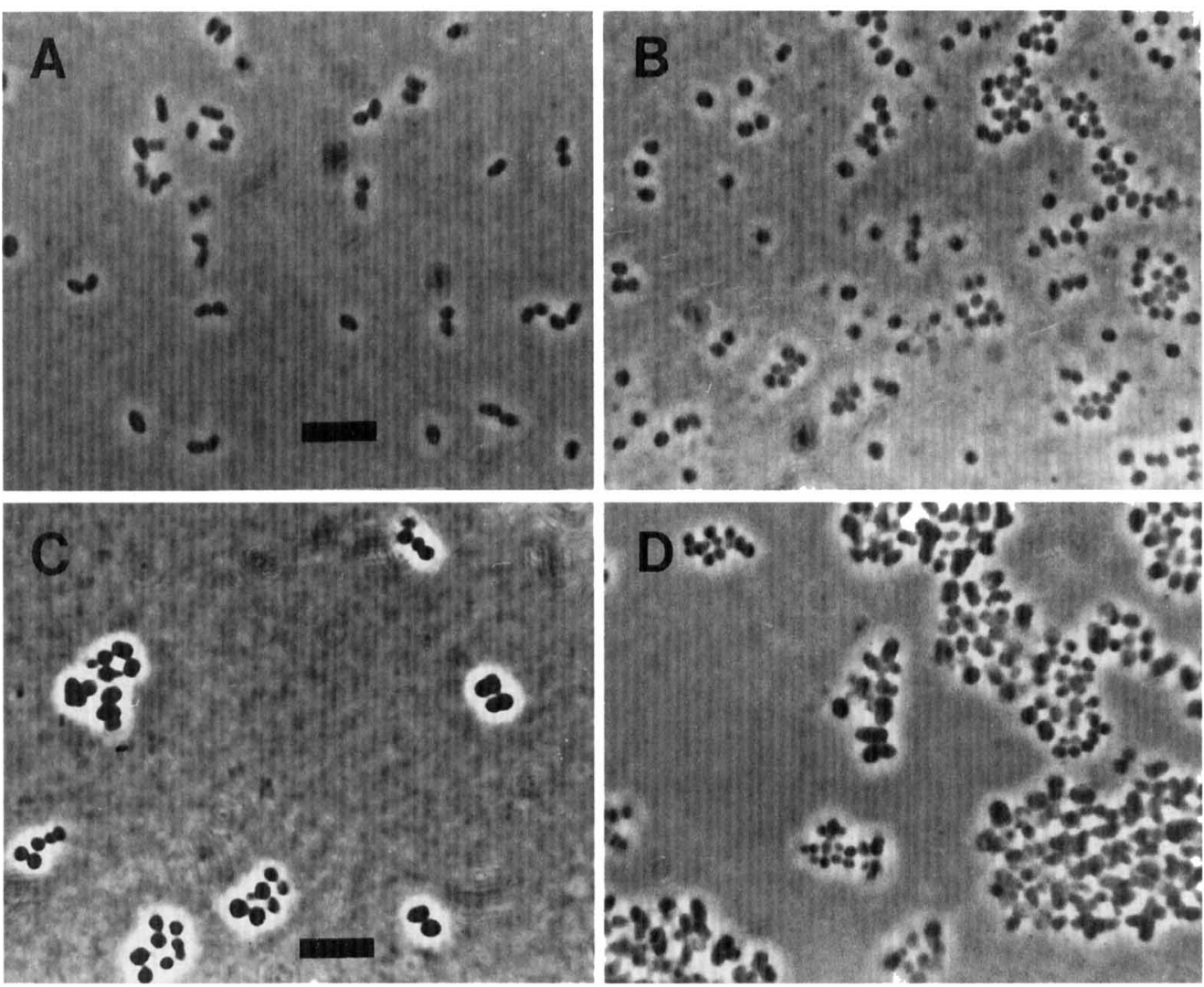

and $3 \mathrm{ml}$ of a $3.5 \%$ potassium tellurite solution per liter were added after the medium was cooled to $50^{\circ} \mathrm{C}$

Lipase activity was determined on tributyrin agar containing (per liter) $2.5 \mathrm{~g}$ of meat extract, $2.5 \mathrm{~g}$ of casein peptone, $3 \mathrm{~g}$ of yeast extract, $10 \mathrm{ml}$ of glyceroltributyrate, and $12 \mathrm{~g}$ of agar ( $\mathrm{pH} 7.5$ ). Gas production was determined in culture medium by using a Durham tube. Urease production was examined on the urea agar base of Christensen (Merck) to which $5 \mathrm{ml}$ of a $40 \%$ urea solution was added after the medium was cooled to $50^{\circ} \mathrm{C}$. Denitrification was examined in nitrate broth (Merck). A control medium without $\mathrm{KNO}_{3}$ was included. Tolerance to $\mathrm{NaCl}$ was tested in culture medium containing 0 to $20 \% \mathrm{NaCl}$. Susceptibility to antibiotics was tested in culture medium containing penicillin $\mathrm{G}$, cycloserine, chloramphenicol, streptomycin, rifampin, kanamycin, or bacitracin (each at a concentration of $0.5 \mathrm{mg} / \mathrm{ml}$ ). The presence of catalase was tested by applying $3 \%$ $\mathrm{H}_{2} \mathrm{O}_{2}$ to colonies grown on solid medium. Oxidase activity was determined by using the modified oxidase test of Faller and Schleifer (8).

Chemotaxonomic characteristics. Fatty acids were isolated by the method of Minnikin et al. (19), and fatty acid contents were determined by gas-liquid chromatography as described by Kroppenstedt and Kutzner (15). Menaquinones were isolated by the method of Collins et al. (7) and were identified by highperformance liquid chromatography (HPLC) (14). Cell walls were prepared and total amino acids were analyzed as described previously (24). Phosphorus contents were determined by the method of Ames (3). The erythritol, sugars, and glucosamine in teichoic acids or polysaccharides in the cell walls were analyzed by gas-liquid chromatography as described previously (24). Diaminoglucuronic acid was detected with an amino acid analyzer (Biotronic), and diaminoglucuronic acid contents were determined by using trifluoroacetic acid hydrolysates ( 2 $\mathrm{M}$ trifluoroacetic acid, $\left.3 \mathrm{~h}, 100^{\circ} \mathrm{C}\right)$ or hydrofluoric acid hydrolysates $(60 \% \mathrm{HF}, 16$ $\mathrm{h}, 0^{\circ} \mathrm{C}$ [4]; followed by treatment with $2 \mathrm{M}$ trifluoroacetic acid). The glycolic acid contents of cell wall hydrolysates $\left(4 \mathrm{M} \mathrm{HCl}, 1 \mathrm{~h}, 100^{\circ} \mathrm{C}\right)$ were determined by cation-exchange HPLC by using an Aminex HPX-87H column and the method described by Guerrant et al. (10).

Sequence determination. DNA purification, in vitro amplification of $16 \mathrm{~S}$ rRNAencoding DNA, and direct sequencing of amplified DNA were performed as described previously (26).

Phylogenetic analysis. 16S rRNA sequences were compared with about 1,800 homologous primary structures from bacteria $(16,20)$ by using the alignment tool of the ARB program package (28). Phylogenetic analyses were performed by using distance matrix, maximum-parsimony, and maximum-likelihood methods and the corresponding tools of the ARB (28) and PHYLIP (9) program packages, as well as the fastDNAml program (16). The compositions of the data set varied with respect to the reference sequences and the alignment positions included. Positional variations at the individual alignment positions were determined by using the tools of the ARB package and were used as criteria to remove or include variable positions.

Isolation of DNA and DNA-DNA hybridization. Chromosomal DNA was isolated from bacterial cells grown to the early stationary phase by using the method of Marmur (17). The DNA purity and concentrations of DNA were determined spectrophotometrically. DNA-DNA hybridization experiments were performed by using DNA labelled with $\alpha-{ }^{35}$ S-dCTP (Amersham, Little Chalfont, United Kingdom) by nick translation (12). The hybridization experiments were performed on nitrocellulose filters in $2 \times \mathrm{SSC}(1 \times \mathrm{SSC}$ is $0.15 \mathrm{M} \mathrm{NaCl}$ plus $0.015 \mathrm{M}$ sodium citrate, $\mathrm{pH} 7.0$ ) at $68^{\circ} \mathrm{C}$ for $20 \mathrm{~h}$. Nonspecifically bound DNA was removed by stringent washing in $0.1 \times$ SSC containing $0.1 \%$ sodium dodecyl sulfate for $3 \mathrm{~h}$ at $68^{\circ} \mathrm{C}$. The DNA reassociation rates were determined at the beginning of saturation (45 $\mu \mathrm{g}$ of DNA) by measuring ${ }^{35} \mathrm{~S}$ contents with a scintillation counter (model MR 300; Kontron). DNA from A. globiformis DSM $20124^{\mathrm{T}}$ was used as the negative control.

DNA base composition. The average guanine-plus-cytosine $(G+C)$ molar ratio of DNA was determined by the thermal denaturation method (18). Reference DNA was obtained from Micrococcus luteus DSM $20030^{\mathrm{T}}$

Nucleotide sequence accession numbers. The nucleotide sequences of strain CNRZ $925^{\mathrm{T}}$, strain CNRZ $926^{\mathrm{T}}$, B. faecium DSM $4810^{\mathrm{T}}$, B. nesterenkovii DSM $9573^{\mathrm{T}}$, B. conglomeratum NCIMB 9859 , and D. hominis DSM $7083^{\mathrm{T}}$ have been deposited in the EMBL Data Library under accession numbers X91031, X91657, X91032, X91033, X91030, and X91034, respectively.

\section{RESULTS}

Cultural and morphological properties. In the exponential phase of growth strains CNRZ $925^{\mathrm{T}}$ and CNRZ $926^{\mathrm{T}}$ were nonmotile, club-shaped rods that occurred in pairs. After $48 \mathrm{~h}$ the cells reached the stationary phase and became irregular cocci that occurred in small (CNRZ $\left.925^{\mathrm{T}}\right)$ or relatively large (CNRZ 926 ${ }^{\mathrm{T}}$ ) agglomerations (Fig. 1). 
TABLE 1. Characteristics which vary in Brachybacterium strains and strains CNRZ $925^{\mathrm{T}}$ and CNRZ $926^{\mathrm{T}}$

\begin{tabular}{|c|c|c|c|c|c|c|c|}
\hline Characteristic & $\begin{array}{c}\text { Strain } \\
\text { CNRZ } 925^{\mathrm{T}}\end{array}$ & $\begin{array}{c}\text { Strain } \\
\text { CNRZ } 926^{\mathrm{T}}\end{array}$ & $\begin{array}{c}\text { Strain } \\
\text { DSM } 4810^{\mathrm{T}}\end{array}$ & $\begin{array}{c}\text { Strain } \\
\text { DSM } 9573^{\mathrm{T}}\end{array}$ & $\begin{array}{c}\text { Strain } \\
\text { CCM } 2432\end{array}$ & $\begin{array}{c}\text { Strain } \\
\text { NCIMB } 9859\end{array}$ & $\begin{array}{c}\text { Strain } \\
\text { CCM } 2136\end{array}$ \\
\hline Growth & Facultative & Facultative & Aerobic & Facultative & Facultative & Aerobic & Aerobic \\
\hline Acid produced from glucose anaerobically & - & - & & + & + & & \\
\hline pH optimum & 7.3 & 7.3 & 7.3 & 7.0 & 7.0 & 7.3 & 7.3 \\
\hline Tolerance to $\mathrm{NaCl}(\%)$ & 14 & 16 & 8 & 6 & 11 & 13 & 11 \\
\hline Gelatin hydrolysis & + & + & - & - & + & + & + \\
\hline Starch hydrolysis & - & - & + & + & + & + & + \\
\hline Urease activity & Inducible & - & - & - & - & - & - \\
\hline \multicolumn{8}{|l|}{ Utilization of amino acids ${ }^{a}$} \\
\hline Aspartate & - & - & + & - & - & - & - \\
\hline Glutamate & + & + & - & - & + & + & - \\
\hline Threonine & - & + & + & + & + & + & - \\
\hline Serine & - & + & - & + & + & + & + \\
\hline Glycine & - & + & - & + & + & + & - \\
\hline Alanine & - & + & + & - & + & + & - \\
\hline \multicolumn{8}{|l|}{ Susceptibility to antibiotics ${ }^{b}$} \\
\hline Chloramphenicol & + & + & + & - & - & + & + \\
\hline Streptomycin & + & + & + & - & - & - & - \\
\hline Rifampin & + & + & + & - & - & + & + \\
\hline Kanamycin & + & + & + & - & + & - & + \\
\hline Bacitracin & + & + & + & - & + & + & + \\
\hline $\mathrm{G}+\mathrm{C}$ content $(\mathrm{mol} \%)$ & 73.0 & 73.0 & $69.4^{c}$ & $70.0^{d}$ & $71.2^{e}$ & $71.5^{e}$ & $70.6^{e}$ \\
\hline
\end{tabular}

"Amino acid utilization when a mixture of the 20 naturally occurring amino acids was included in the medium.

${ }^{b}$ All strains were susceptible to penicillin $\mathrm{G}$ and cycloserine.

"Data from reference 6.

"Data from reference 11 .

'Data from reference 13.

After 2 days on agar media both strains formed mediumsized, smooth, circular, low-convex colonies with entire margins (diameter, 3 to $5 \mathrm{~mm}$ ). The colors of the colonies of strains CNRZ $925^{\mathrm{T}}$ and CNRZ $926^{\mathrm{T}}$ were vivid lemon and pale flaxen, respectively.

Growth occurred at temperatures above $20^{\circ} \mathrm{C}$, and optimal growth occurred at $30^{\circ} \mathrm{C}$. No growth occurred at $\geq 37^{\circ} \mathrm{C}$. The doubling times at $30^{\circ} \mathrm{C}$ in the culture medium used were 1.25 $\mathrm{h}\left(\mathrm{CNRZ} 925^{\mathrm{T}}\right)$ and $2.75 \mathrm{~h}\left(\mathrm{CNRZ} 926^{\mathrm{T}}\right)$.

Biochemical properties. We determined biochemical characteristics of strains CNRZ $925^{\mathrm{T}}$ and CNRZ $926^{\mathrm{T}}$, B. faecium DSM $4810^{\mathrm{T}}$, B. nesterenkovii DSM $9573^{\mathrm{T}}$ and CCM 2432, and B. conglomeratum CCM 2136 and NCIMB 9859. All of these strains exhibited catalase and oxidase activities but not lecithinase activity. None hydrolyzed casein or tributyrin. None utilized tyrosine or xanthine. All reduced nitrate to nitrite. These organisms utilized fructose, sucrose, maltose, and lactose and produced acid but no gas from glucose under aerobic conditions. They did not produce indole. The ammonification test was positive for all strains, and all strains were denitrification negative. All were able to reduce tellurite. Characteristics which could be used to discriminate among the strains are shown in Table 1.

Chemotaxonomic characteristics. All of the strains contained menaquinones in their respiratory chains. The major menaquinone was an unsaturated menaquinone with seven isoprenoid units (MK-7). In addition, minor amounts of MK-8 were present in most strains; the only exception was strain CNRZ $925^{\mathrm{T}}$, which contained substantial amounts of MK-8 (Table 2).

The amino acids present in all cell wall hydrolysates were alanine, glutamic acid, and meso-diaminopimelic acid (molar ratio, 2:2/3:1). In addition, glycine and amide groups were found in strains CNRZ $925^{\mathrm{T}}$, CNRZ $926^{\mathrm{T}}$, DSM $4810^{\mathrm{T}}$, and NCIMB 9859. In strains CNRZ $925^{\mathrm{T}}$ and CNRZ $926^{\mathrm{T}}$ one of the three glutamate residues was replaced by aspartate. Glycolic acid was present in all strains. The detailed compositions of the peptidoglycan constituents are shown in Table 2.

Galactose and glucosamine were found in the cell walls of most strains; the only exception was strain CCM 2136, whose cell walls lacked glucosamine. In addition, glucose was present in strains NCIMB 9859 and CCM 2136, rhamnose was present in strains DSM $9573^{\mathrm{T}}$ and CCM 2432, and erythritol and $N, N^{\prime}$ diacetyl-2,3-dideoxy-2,3-diaminoglucuronic acid were present in strains CNRZ $925^{\mathrm{T}}$, CNRZ 926 ${ }^{\mathrm{T}}$, and DSM $4810^{\mathrm{T}}$. Phosphorus was present in strains CNRZ $925^{\mathrm{T}}$, CNRZ $926^{\mathrm{T}}$, and DSM $4810^{\mathrm{T}}$. Detailed compositions are shown in Table 2 .

We found that iso and anteiso fatty acids predominated in the fatty acid patterns of the strains which we investigated. The major fatty acid was 12-methyltetradecanoic acid (anteiso- $\mathrm{C}_{15}$ : o). Other fatty acids (iso, anteiso, and nonbranched fatty acids) occurred in minor amounts (up to $10 \%$ ). The detailed fatty acid compositions of the strains are shown in Table 3.

Phylogenetic considerations. We determined almost complete $16 \mathrm{~S}$ rRNA gene sequences for strains CNRZ $925^{\mathrm{T}}$ and CNRZ $926^{\mathrm{T}}, B$. faecium DSM $4810^{\mathrm{T}}$, B. nesterenkovii DSM $9573^{\mathrm{T}}$, B. conglomeratum NCIMB 9859, and D. hominis DSM $7083^{\mathrm{T}}$. A matrix of the overall levels of $16 \mathrm{~S}$ rRNA primary structure similarity for the bacteria which we investigated is shown in Table 4 . The $16 \mathrm{~S}$ rRNA sequence of $D$. hominis was nearly identical to the sequence described by Cai and Collins (5). The closest relatives of strains CNRZ $925^{\mathrm{T}}$ and CNRZ $926^{\mathrm{T}}$ were $B$. faecium and $B$. conglomeratum, as indicated by similarity values ranging from 97.1 to $97.5 \%$, whereas $B$. nesterenkovii was less closely related (similarity values, 97.2 and $96.9 \%$ ). The corresponding similarity values for $D$. hominis and 
TABLE 2. Chemotaxonomic characteristics

\begin{tabular}{|c|c|c|c|c|c|c|c|c|c|c|c|c|c|c|c|c|c|c|}
\hline \multirow{3}{*}{ Strain } & \multirow{2}{*}{\multicolumn{2}{|c|}{$\begin{array}{c}\text { Menaquinone } \\
\text { composition } \\
(\%)\end{array}$}} & \multicolumn{16}{|c|}{ Relative amt of cell wall components } \\
\hline & & & \multicolumn{9}{|c|}{ Amino acids } & \multicolumn{7}{|c|}{ Sugars and phosphate } \\
\hline & MK-7 & MK-8 & Asp & Mur & Glu & Gly & Ala & $m-\mathrm{Dpm}^{a}$ & GlcN & $\mathrm{NH}_{3}$ & $\begin{array}{c}\text { Glycolic } \\
\text { acid }^{b}\end{array}$ & $\begin{array}{l}\text { Eryth- } \\
\text { ritol }\end{array}$ & $P_{i}$ & GlcUANAc ${ }^{c}$ & $\begin{array}{c}\text { Rham- } \\
\text { nose }\end{array}$ & Gal & Glc & GlcN \\
\hline CNRZ $925^{\mathrm{T}}$ & 64.4 & 35.6 & 1.34 & 0.83 & 2.19 & 1.15 & 1.96 & 1 & 1.28 & 2.07 & + & 0.63 & 1.86 & 0.21 & & 1 & & 1.13 \\
\hline CNRZ $926^{\mathrm{T}}$ & 91.8 & 8.2 & 1.07 & 0.88 & 1.95 & 1.14 & 1.87 & 1 & 1.36 & 1.83 & + & 1.61 & 1.61 & 0.16 & & 1 & 0.14 & 0.53 \\
\hline DSM $4810^{\mathrm{T}}$ & $\mathrm{ND}^{d}$ & ND & & 0.87 & 2.66 & 0.98 & 1.66 & 1 & 1.48 & 0.76 & + & 0.43 & 0.41 & $<0.08^{e}$ & & 1 & 0.37 & 0.21 \\
\hline CCM 2432 & 99.9 & & & 0.79 & 2.94 & & 1.79 & 1 & 2.18 & 0.37 & + & & & & 0.70 & 1 & & 0.19 \\
\hline NCIMB 9859 & 90.4 & 9.6 & & 0.83 & 3.10 & 0.99 & 1.97 & 1 & 1.43 & 1.53 & + & & & & & 1 & 0.56 & 0.30 \\
\hline CCM 2136 & 90.7 & 9.3 & & 0.81 & 2.77 & 1.15 & 1.92 & 1 & 1.14 & 1.48 & + & & & & & 1 & 0.25 & \\
\hline
\end{tabular}

${ }^{a} m$-Dpm, meso-diaminopimelic acid.

${ }^{b}$ Qualitative estimate.

' GlcUANAc, $N, N^{\prime}$-diacetyl-2,3-diamino-2,3-dideoxyglucuronic acid.

"ND, not detected.

' As no commercial N,N'-diacetyl-2,3-diamino-2,3-dideoxyglucuronic acid was available, the actual amount could not be determined without investigating of teichoic acid fragments; $80 \%$ of the erythritol was unsubstituted (amount of erythritol liberated by HF compared with the total amount of erythritol). The amount of acetate as substituent was not determined.

the brachybacteria were considerably lower $(94.1$ to $94.8 \%)$. All other currently available $16 \mathrm{~S}$ rRNA sequences of grampositive bacteria with high DNA $\mathrm{G}+\mathrm{C}$ contents are less than $94.2 \%$ similar to the sequences of the previously described brachybacteria and strains CNRZ $925^{\mathrm{T}}$ and CNRZ $926^{\mathrm{T}}$. The phylogenetic relationships of the organisms which we studied and a selection of related reference organisms are shown in Fig. 2.

DNA-DNA hybridization. The results of DNA-DNA hybridization experiments are shown in Table 5. The DNA-DNA complementarity values for strains CNRZ $925^{\mathrm{T}}$ and CNRZ $926^{\mathrm{T}}$ were 10.8 and $17.7 \%$ in a reverse experiment. The complementarity values for strain CNRZ $925^{\mathrm{T}}$ and the previously described brachybacteria which we investigated ranged from 11.4 to $38.1 \%$, and the complementarity values for strain CNRZ $926^{\mathbf{T}}$ and the previously described brachybacteria ranged from 11.8 to $35.8 \%$. The levels of DNA relatedness between $A$. globiformis DSM $20124^{\mathrm{T}}$ and the brachybacteria were not significant ( 0 to $2.4 \%$ ).

\section{DISCUSSION}

The taxonomic position of a number of strains that exhibit peptidoglycan variation $\mathrm{A} 4 \gamma$ of Schleifer and Kandler (22) has been uncertain. These bacteria have been placed in the genera Micrococcus and Arthrobacter $(11,22)$, and on the basis of DNA-DNA hybridization data, Schleifer and Lang (23) placed them in a separate genus, which they did not define further. Later, Collins et al. (6) described the genus Brachybacterium for some of these strains. Gvozdyak et al. (11) found that several strains isolated from dairy products belonged to a new species of this genus, and recently, Takeuchi et al. (29) described three additional species of the genus Brachybacterium, bringing the number of species in this genus to five (B. faecium Collins, Brown, and Jones 1988, B. nesterenkovii Gvozdyak, Nogina, and Schumann 1992, B. conglomeratum Takeuchi, Fang, and Yokota 1995, Brachybacterium paraconglomeratum Takeuchi, Fang, and Yokota 1995, and Brachybacterium rhamnosum Takeuchi, Fang, and Yokota 1995). The main chemotaxonomic characteristic of these species is the occurrence of peptidoglycan variation A4 $\gamma$ [meso-diaminopimelic acid-(DGlu $)_{2}$ type] (22). A glycine amide substitution at the $\alpha$-carboxyl group of D-Glu in the peptidoglycan does not occur in $B$. nesterenkovii. Muramic acid occurs mostly in the glycolylated form instead of the acetylated form (29). In all species, the principal menaquinone is $\mathrm{MK}-7$; the principal fatty acids are anteiso- $\mathrm{C}_{15: 0}$ and anteiso- $\mathrm{C}_{17: 0}$ acids. The $\mathrm{G}+\mathrm{C}$ contents of the DNAs of these species range from 68 to $72 \mathrm{~mol} \%$. The main sugars in cell walls are galactose and glucose; in $B$. rhamnosum and $B$. nesterenkovii rhamnose is also found (29).

Like $B$. nesterenkovii, the strains described in this paper were isolated from dairy products (Beaufort and Gruyère cheeses), and they have similar characteristics. The peptidoglycans of these strains are variation $\mathrm{A} 4 \gamma$ peptidoglycans but differ from the peptidoglycans of the previously described brachybacteria. They contain D-Asp-D-Glu rather than D-Glu ${ }_{2}$ as the interpeptide bridge. The $\alpha$-carboxyl group of D-glutamic acid in the peptide subunit is replaced by glycine amide, as is the case in most previously described brachybacteria. Muramic acid occurs in the $N$-glycolylated form. The principal menaquinone is

TABLE 3. Fatty acid compositions of strains CNRZ $925^{\mathrm{T}}$ and CNRZ $926^{\mathrm{T}}$ and other Brachybacterium strains

\begin{tabular}{|c|c|c|c|c|c|c|c|c|c|c|c|c|c|}
\hline \multirow{2}{*}{ Strain } & \multicolumn{13}{|c|}{ Fatty acid composition (\%) ${ }^{a}$} \\
\hline & $i-C_{14: 0}$ & $\mathrm{C}_{14: 0}$ & $\mathrm{i}-\mathrm{C}_{15: 0}$ & ai- $C_{15: 0}$ & $i-C_{16: 0}$ & $\mathrm{C}_{16: 1}$ & $\mathrm{C}_{16: 0}$ & $\mathrm{i}-\mathrm{C}_{17: 0}$ & ai- $\mathrm{C}_{17: 0}$ & $\mathrm{C}_{18: 0}$ & $C_{18: 1 \omega 9}$ & $\mathrm{C}_{18: 1 \omega 7}$ & $\mathrm{C}_{19 \mathrm{c}}$ \\
\hline CNRZ $925^{\mathrm{T}}$ & & & 1.0 & $64.3^{b}$ & 4.1 & & 2.7 & & 5.3 & 5.7 & 3.8 & 5.9 & 7.2 \\
\hline CNRZ 926 ${ }^{\mathrm{T}}$ & 1.5 & 1.6 & & $69.1^{b}$ & 4.3 & 2.5 & 1.3 & & 3.0 & 1.9 & & 8.1 & 6.7 \\
\hline CCM 2432 & 2.1 & 3.3 & 4.5 & $57.2^{b}$ & 2.9 & & 8.8 & & 12.8 & 3.1 & & & 5.3 \\
\hline NCIMB 9859 & 8.2 & 12.4 & 4.2 & 15.8 & $19.9^{b}$ & & 17.1 & & 9.2 & 6.5 & & 4.3 & 2.4 \\
\hline CCM 2136 & 0.7 & 0.6 & 6.2 & $37.6^{b}$ & 15.8 & & 4.8 & 4.1 & 23.3 & 2.6 & & 2.0 & 2.3 \\
\hline
\end{tabular}

"The abbreviations for fatty acids are illustrated by the following examples: $\mathrm{C}_{16: 0}$, hexadecanoic acid; $\mathrm{C}_{16: 1}$, hexadecenoic acid; i- $\mathrm{C}_{15: 0}, 13$-methyltetradecanoic acid ai- $\mathrm{C}_{15: 0}$, 12-methyltetradecanoic acid; $\mathrm{C}_{18: 1 \omega 9}$, cis-9,10-octadecenoic acid; $\mathrm{C}_{1 \%}$, cyclopropanenonadecanoic acid.

${ }^{b}$ Major component. 
TABLE 4. Similarity matrix based on $16 \mathrm{~S}$ rRNA sequences

\begin{tabular}{|c|c|c|c|c|c|c|c|c|c|c|c|c|c|c|c|c|}
\hline \multirow[b]{2}{*}{ Organism } & \multicolumn{16}{|c|}{$\%$ 16S rRNA sequence similarity } \\
\hline & 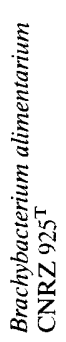 & 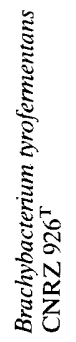 & 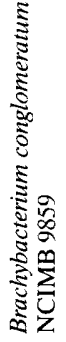 & 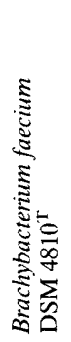 & 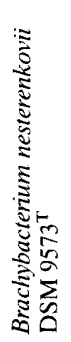 & 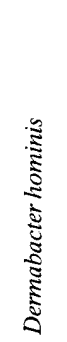 & 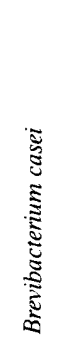 & 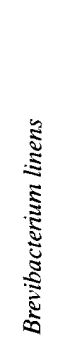 & 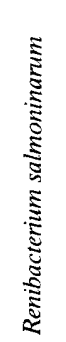 & 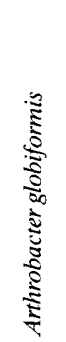 & 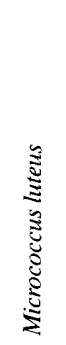 & 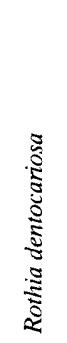 & 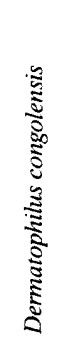 & 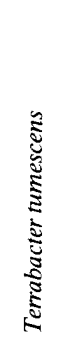 & 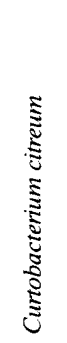 & 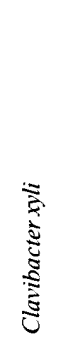 \\
\hline Brachybacterium tyrofermentans CNRZ $926^{\mathrm{T}}$ & 98.7 & & & & & & & & & & & & & & & \\
\hline Brachybacterium conglomeratum NCIMB 9859 & 97.4 & 97.1 & & & & & & & & & & & & & & \\
\hline Brachybacterium faecium DSM $4810^{\top}$ & 97.5 & 97.3 & 98.1 & & & & & & & & & & & & & \\
\hline Brachybacterium nesterenkovii DSM $9573^{\mathrm{T}}$ & 97.2 & 96.9 & 96.4 & 97.1 & & & & & & & & & & & & \\
\hline Dermabacter hominis & 94.8 & 94.1 & 94.6 & 94.3 & 94.7 & & & & & & & & & & & \\
\hline Brevibacterium casei & 90.0 & 90.4 & 90.4 & 90.8 & 90.9 & 90.1 & & & & & & & & & & \\
\hline Brevibacterium linens & 90.1 & 90.3 & 90.7 & 90.3 & 90.9 & 90.1 & 97.1 & & & & & & & & & \\
\hline Renibacterium salmoninarum & 91.3 & 91.4 & 91.2 & 91.3 & 91.9 & 91.2 & 89.6 & 89.8 & & & & & & & & \\
\hline Arthrobacter globiformis & 93.6 & 93.6 & 93.7 & 93.6 & 94.2 & 92.9 & 90.8 & 90.5 & 95.4 & & & & & & & \\
\hline Micrococcus luteus & 92.7 & 92.7 & 92.5 & 92.7 & 93.1 & 92.7 & 90.5 & 90.0 & 93.7 & 95.8 & & & & & & \\
\hline Rothia dentocariosa & 91.2 & 91.1 & 91.0 & 91.0 & 91.7 & 91.3 & 90.3 & 90.9 & 92.5 & 93.9 & 93.9 & & & & & \\
\hline Dermatophilus congolensis & 91.5 & 91.1 & 91.1 & 91.1 & 92.0 & 91.7 & 90.0 & 90.2 & 91.8 & 92.5 & 92.5 & 92.3 & & & & \\
\hline Terrabacter tumescens & 92.4 & 92.2 & 92.0 & 92.8 & 93.7 & 91.6 & 90.6 & 90.5 & 90.5 & 92.7 & 92.6 & 91.9 & 92.7 & & & \\
\hline Curtobacterium citreum & 91.5 & 91.5 & 91.1 & 91.5 & 92.4 & 90.9 & 90.5 & 89.9 & 91.9 & 93.2 & 93.0 & 92.0 & 92.8 & 92.6 & & \\
\hline Clavibacter xyli & 91.3 & 91.4 & 91.0 & 91.5 & 91.9 & 90.3 & 90.2 & 89.8 & 90.2 & 92.0 & 92.0 & 90.7 & 90.7 & 91.8 & 94.8 & \\
\hline Microbacterium arborescens & 90.0 & 90.0 & 89.4 & 90.1 & 91.2 & 89.3 & 89.1 & 89.0 & 90.3 & 91.0 & 91.5 & 90.4 & 90.8 & 91.3 & 94.1 & 93.5 \\
\hline
\end{tabular}

MK-7, but MK-8 is also present in substantial amounts in strain CNRZ $925^{\mathrm{T}}$ (Table 2). The fatty acids are primarily straight-chain, saturated, iso- and anteiso-methyl, branched fatty acids; 12 -methyltetradecanoic (anteiso- $\mathrm{C}_{15: 0}$ ) acid is the predominant fatty acid in strains CNRZ $925^{\mathrm{T}}$ and CNRZ $926^{\mathrm{T}}$ ( 64.3 and $69.1 \%$ of the total fatty acids, respectively) (Table 3 ). Other fatty acids are present at levels of less than $10 \%$. Thus, strains CNRZ $925^{\mathrm{T}}$ and CNRZ $926^{\mathrm{T}}$ clearly differ from the previously described brachybacteria, which contain 37.6 to $57.2 \%$ 12-methyltetradecanoic (anteiso- $\mathrm{C}_{15: 0}$ ) acid and substantial amounts of 14-methylhexadecanoic (anteiso- $\mathrm{C}_{17: 0}$ ) acid (Table 3 ).

Our results also demonstrated that teichoic acids with the unusual compound erythritol as the polyol and diaminoglucuronic acid as a substituent occur in strains CNRZ $925^{\mathrm{T}}$ and CNRZ $926^{\mathrm{T}}(24)$. In addition to the teichoic acids, galactose $\left(\mathrm{CNRZ} 925^{\mathrm{T}}\right)$ or galactose and glucose $\left(\mathrm{CNRZ} 926^{\mathrm{T}}\right)$ were found to constitute separate polysaccharides in the cell walls. An investigation of the cell walls of $B$. faecium DSM $4810^{\mathrm{T}}$ revealed a similar cell wall structure; erythritol, phosphorus, diaminoglucuronic acid, glucosamine, galactose, and glucose occurred in the cell walls of this organism. On the basis of the results of the cell wall analysis alone we could not determine which constituents belonged to the teichoic acid. Assuming that the cell wall compositions of strains DSM $4810^{\mathrm{T}}$, CNRZ $925^{\mathrm{T}}$, and CNRZ $926^{\mathrm{T}}$ are similar, glucose and galactose probably form a separate polysaccharide. Thus, B. faecium, the type species of the genus Brachybacterium (6), is obviously similar to strains CNRZ $925^{\mathrm{T}}$ and CNRZ $926^{\mathrm{T}}$ in cell wall structure. Gvozdyak et al. (11) described the occurrence of rhamnose in $B$. nesterenkovii cells, whereas no rhamnose was present in $B$. faecium. Recently, Takeuchi et al. (29) showed that rhamnose occurs in the cell walls of $B$. nesterenkovii. Our investigation of cell walls, which included extraction of accessory polymers, confirmed this finding and corroborated the hypothesis that galactose occurs in the cell walls of Brachybacterium strains. However, our experiments revealed that glucose is not a cell wall constituent in $B$. nesterenkovii and that 6-deoxytalose is not a cell wall constituent in $B$. faecium (29). Instead ( $B$. nesterenkovii) or in addition (B. faecium), glucosamine was found. The reason for these differences in the compositions of the carbohydrate moieties of the cell walls is not clear, but the differences might be due to nutritional differences (i.e., addition of brain heart infusion to the culture medium) (29). In this context it seems important to emphasize that when accessory carbohydrate polymers in bacterial cell walls are examined, taxonomically relevant data can be obtained only when polysaccharides and/or teichoic acids are extracted, fractionated, and structurally investigated.

We believe that the chemotaxonomic data described above indicate that strains CNRZ $925^{\mathrm{T}}$ and CNRZ $926^{\mathrm{T}}$ belong to the genus Brachybacterium. This view was clearly validated by $16 \mathrm{~S}$ rRNA sequence data. For each of these isolates the levels of sequence similarity to $B$. faecium and B. conglomeratum, the closest relatives, were more than $97 \%$, indicating that the organisms are related at the genus level or possibly at the species level. DNA-DNA hybridization experiments performed with B. faecium DSM $4810^{\mathrm{T}}, B$. nesterenkovii DSM $9573^{\mathrm{T}}, B$. conglomeratum NCIMB 9859, strain CNRZ $925^{\mathrm{T}}$, and strain CNRZ $926^{\mathrm{T}}$ resulted in values well below $70 \%$, the level of relatedness which separates organisms at the species level (27). The levels of DNA relatedness to $B$. faecium DSM $4810^{\mathrm{T}}, B$. nesterenkovii DSM $9573^{\mathrm{T}}$, and $B$. conglomeratum NCIMB 9859 were between 11.4 and $38.1 \%$ for both CNRZ $925^{\mathrm{T}}$ and CNRZ $926^{\mathrm{T}}$; these values were similar to the values obtained by Gvozdyak et al. (11) for the relationship between B. nesterenkovii and B. faecium (22\%) and by Takeuchi et al. (29) for the relationships among the five Brachybacterium species which they investigated ( 2 to $49 \%$ ). The $16 \mathrm{~S}$ rRNA sequence data and the DNA-DNA hybridization data clearly showed that 


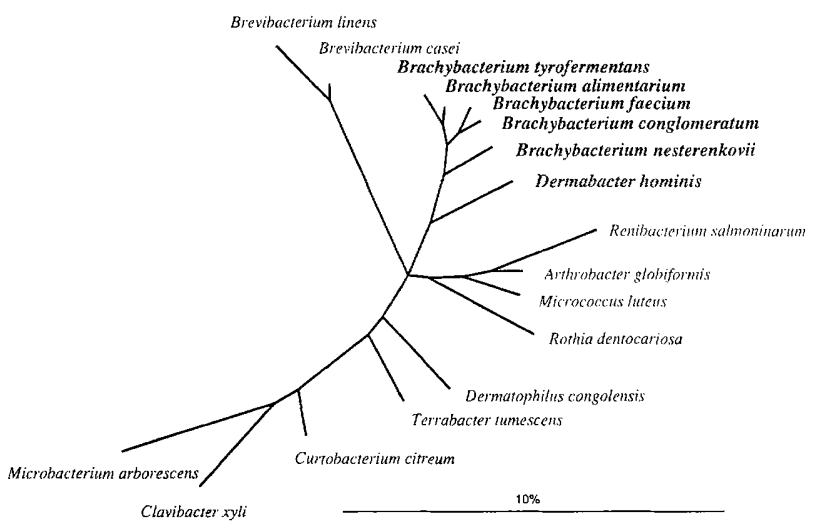

FIG. 2. Tree based on the results of a maximum-likelihood analysis of a subset of 16S rRNA sequences from gram-positive bacteria with high DNA G+C contents that were the 40 closest relatives of strains CNRZ $925^{\mathrm{T}}$ and CNRZ $926^{\mathrm{T}}$. The topology of the tree was evaluated by performing distance matrix and maximum-parsimony analyses of more comprehensive data sets containing all available $16 \mathrm{~S}$ rRNA sequences from gram-positive bacteria with high DNA G $+\mathrm{C}$ contents and selected representatives of all known bacterial phyla. Only alignment positions which were occupied by identical residues in at least $50 \%$ of all available homologous sequences from gram-positive bacteria with high DNA $\mathrm{G}+\mathrm{C}$ contents were included in the calculations. The inclusion of more variable positions did not alter the topology of the subtree containing strains CNRZ $925^{\mathrm{T}}$ and CNRZ $926^{\mathrm{T}}$ and Brachybacterium and Dermabacter strains. Multifurcations in the tree are branches for which a relative order could not be determined unambiguously or a common branching order was not significantly supported when different treeing methods were used. Bar $=10 \%$ estimated sequence divergence.

CNRZ $925^{\mathrm{T}}$ and CNRZ $926^{\mathrm{T}}$ are not members of previously described Brachybacterium species. The levels of DNA relatedness between CNRZ $925^{\mathrm{T}}$ and CNRZ $926^{\mathrm{T}}$, corresponding to hybridization values of 10.8 and $17.7 \%$ (Table 5), also indicate that these organisms belong to separate species.

Our findings indicate that CNRZ $925^{\mathrm{T}}$ and $\mathrm{CNRZ} 926^{\mathrm{T}}$ represent two new species of the genus Brachybacterium. We propose the name Brachybacterium alimentarium for CNRZ $925^{\mathrm{T}}$ and the name Brachybacterium tyrofermentans for CNRZ $926^{\mathrm{T}}$.

Description of Brachybacterium alimentarium sp. nov. Brachybacterium alimentarium (a.li.men.ta'ri.um. L. neut. adj. alimentarium, pertaining to food) surface colonies are medium sized, vivid lemon colored, low convex, and smooth. Cells vary in shape from coccoid forms in the stationary phase, which occur in small clusters of four to eight cells, to club-shaped rods in the exponential phase, which occur in pairs. Facultatively anaerobic. The optimum temperature is $30^{\circ} \mathrm{C}$, and the optimum $\mathrm{pH}$ is 7.3. Acid is produced from glucose, but not from

TABLE 5. DNA-DNA hybridization data for strains CNRZ $925^{\mathrm{T}}$ and CNRZ $926^{\mathrm{T}}$ and other Brachybacterium strains

\begin{tabular}{lccc}
\hline $\begin{array}{c}\text { Source of } \\
\text { unlabelled } \\
\text { DNA }\end{array}$ & \multicolumn{3}{c}{ \% DNA relatedness with ${ }^{35}$ S-labelled DNA from: } \\
\cline { 2 - 4 } & CNRZ 925 & CNRZ 926 & DSM 20124 ${ }^{\mathrm{T} a}$ \\
\hline CNRZ 925 & 100 & 17.7 & 0.6 \\
CNRZ 926 & 10.8 & 100 & \\
DSM 4810 & 19.4 & 35.8 & \\
DSM 9573 & 16.4 & 11.8 & 1.3 \\
CCM 2432 & 11.4 & 21.5 & 2.4 \\
NCIMB 9859 & 38.1 & 26.2 & 0.6 \\
CCM 2136 & 14.3 & 23.1 & 100 \\
DSM 20124 & 2.0 & & \\
\hline
\end{tabular}

${ }^{a}$ A. globiformis DSM $20124^{\mathrm{T}}$ was used as a negative control. fructose, sucrose, maltose, and lactose. Catalase and oxidase positive. Gelatin is hydrolyzed. Starch, casein, and tributyrin are not hydrolyzed. Tyrosine and xanthine are not utilized. Urease activity is inducible. Nitrate is reduced to nitrite. Tolerance to $14 \% \mathrm{NaCl}$.

The cell wall peptidoglycan is based on meso-diaminopimelic acid with a D-Asp-D-Glu interpeptide bridge (variation A4y). Two teichoic acids are present; one contains erythritol and $N, N^{\prime}$-diacetyl-2,3-diamino-2,3-dideoxyglucuronic acid, and the other contains $N$-acetylglucosamine and galactose as sugar constituents. The principal menaquinone is MK-7; MK-8 is present in substantial amounts. The long-chain fatty acids are primarily straight-chain, saturated, iso- and anteiso-methyl, branched fatty acids, with 12-methyltetradecanoic (anteiso$\mathrm{C}_{15: 0}$ ) acid predominating. The $\mathrm{G}+\mathrm{C}$ content of the DNA is 73 mol\% (as determined by the thermal denaturation method). Isolated from the surfaces of Beaufort and Gruyère cheeses. The type strain is CNRZ 925.

Description of Brachybacterium tyrofermentans sp. nov. Brachybacterium tyrofermentans (ty.ro.fer.men'tans. Gr. n. tyros, cheese; L. part. adj. fermentans, leavening; N. L. adj. tyrofermentans, fermenting cheese) surface colonies are medium sized, pale flaxen, low convex, and smooth. Cells vary in shape from coccoid forms in the stationary phase, which occur in large agglomerations, to club-shaped rods in the exponential phase, which occur predominantly in pairs or agglomerations of four cells. Facultatively anaerobic. The optimum temperature is $30^{\circ} \mathrm{C}$, and the optimum $\mathrm{pH}$ is 7.3 . Acid is produced from glucose, but not from fructose, sucrose, maltose, and lactose. Catalase and oxidase positive. Gelatin is hydrolyzed. Starch, casein, and tributyrin are not hydrolyzed. Tyrosine and xanthine are not utilized. Urea is not hydrolyzed. Nitrate and nitrite are reduced. Tolerant to $16 \% \mathrm{NaCl}$.

The cell wall peptidoglycan is based on meso-diaminopimelic acid with a D-Asp-D-Glu interpeptide bridge (variation $\mathrm{A} 4 \gamma$ ). One teichoic acid structure is present; this structure contains erythritol, $N$-acetylglucosamine, and $N, N^{\prime}$-diacetyl2,3-diamino-2,3-dideoxyglucuronic acid. The principal menaquinone is MK-7. The long-chain fatty acids are primarily straight-chain, saturated, iso- and anteiso-methyl, branched fatty acids, with 12-methyltetradecanoic (anteiso- $\mathrm{C}_{15: 0}$ ) acid predominating. The $\mathrm{G}+\mathrm{C}$ content of the DNA is $73 \mathrm{~mol} \%$ (as determined by the thermal denaturation method). Isolated from the surfaces of Beaufort and Gruyère cheeses. The type strain is CNRZ 926.

\section{REFERENCES}

1. Accolas, J. P. (Station de Recherches Laitières, Institut National de la Recherche Agronomique). 1989. Personal communication.

2. Accolas, J. P., D. Melcion, and L. Vassal. 1978. Study of the surface microflora of Gruyère and Beaufort cheeses, p. 762. In J. Auclair and E. J. Mann (ed.), XXth International Dairy Congress. Congrilait, Paris.

3. Ames, B. N. 1966. Assay of inorganic phosphate, total phosphate and phosphatases. Methods Enzymol. 8:115-118.

4. Anderson, A. J., R. S. Green, and A. R. Archibald. 1977. Specific determination of ribitol teichoic acid in whole bacteria and isolated walls of Bacillus subtilis W 23. Carbohydr. Res. 57:c7-c10.

5. Cai, J., and M. D. Collins. 1994. Phylogenetic analysis of the meso-diaminopimelic acid-containing genera Brevibacterium and Dermabacter. Int. J. Syst. Bacteriol. 44:583-585.

6. Collins, M. D., J. Brown, and D. Jones. 1988. Brachybacterium faecium gen. nov., sp. nov., a coryneform bacterium from poultry deep litter. Int. J. Syst. Bacteriol. 38:45-48.

7. Collins, M. D., T. Pirouz, M. Goodfellow, and D. E. Minnikin. 1977. Distribution of menaquinones in actinomycetes and corynebacteria. J. Gen. Microbiol. 100:221-230.

8. Faller, A. H., and K. H. Schleifer. 1981. Modified oxidase and benzidine tests for separation of staphylococci from micrococci. J. Clin. Microbiol. 13:10311035.

9. Felsenstein, J. 1982. Numerical methods for inferring phylogenetic trees. Q Rev. Biol. 57:379-404. 
10. Guerrant, G. O., M. A. Lambert, and C. W. Moss. 1982. Analysis of shortchain acids from anaerobic bacteria by high-performance liquid chromatography. J. Clin. Microbiol. 16:355-360.

11. Gvozdyak, O. R., T. M. Nogina, and P. Schumann. 1992. Taxonomic study of the genus Brachybacterium: Brachybacterium nesterenkovii sp. nov. Int. J. Syst. Bacteriol. 42:74-78.

12. Kelly, R. B., N. R. Cozzarelli, M. P. Deutscher, I. R. Lehman, and A. Kornberg. 1970. Enzymatic synthesis of deoxyribonucleic acid. XXXII. Replication of duplex deoxyribonucleic acid by polymerase at a single strand break. J. Biol. Chem. 245:39-45.

13. Kocur, M., T. Bergan, and N. Mortensen. 1971. DNA base composition of gram-positive cocci. J. Gen. Microbiol. 69:167-183.

14. Kroppenstedt, R. M. 1983. Separation of bacterial menaquinones by HPLC using reversed phase (RP 18) and a silver loaded ion exchanger as stationary phase. J. Liq. Chromatogr. 5:2359-2367.

15. Kroppenstedt, R. M., and H. J. Kutzner. 1978. Biochemical taxonomy of some problem actinomycetes, p. 125-133. In M. Mordarski, W. Kurylowicz, and J. Jeljaszewicz (ed.). Nocardia and Streptomyces. Proceedings of the International Symposium on Nocardia and Streptomyces. Gustav Fischer Verlag, Stuttgart, Germany.

16. Larsen, N., G. J. Olsen, B. L. Maidak, M. J. McCaughey, R. Overbeek, T. J. Macke, T. L. Marsh, and C. R. Woese. 1993. The Ribosomal Database Project. Nucleic Acids Res. 21:3021-3023.

17. Marmur, J. 1961. A procedure for the isolation of deoxyribonucleic acid from microorganisms. J. Mol. Biol. 3:208-218.

18. Marmur, J., and P. Doty. 1962. Determination of the base composition of deoxyribonucleic acid from its thermal denaturation temperature. J. Mol. Biol. 5:109-118.

19. Minnikin, D. E., L. Alshamaony, and M. Goodfellow. 1975. Differentiation of Mycobacterium, Nocardia and related taxa by thin layer chromatography analysis of whole organism methylosates. J. Gen. Microbiol. 88:200-204.
20. Neefs, J.-M., Y. Van de Peer, P. De Rijk, S. Chapelle, and R. De Wachter. 1993. Compilation of small ribosomal subunit RNA structures. Nucleic Acids Res. 21:3025-3049.

21. Neidhard, F. C., P. L. Bloch, and D. F. Smith. 1974. Culture medium for enterobacteria. J. Bacteriol. 119:736-747.

22. Schleifer, K. H., and O. Kandler. 1972. Peptidoglycan types of bacterial cell walls and their taxonomic implications. Bacteriol. Rev. 36:407-477.

23. Schleifer, K. H., and K. Lang. 1980. Close relationship among strains of Micrococcus conglomeratus and Arthrobacter species. FEMS Microbiol. Lett. 9:223-226

24. Schubert, K., D. Reiml, J. P. Accolas, and F. Fiedler. 1993. A novel type of meso-diaminopimelic acid-based peptidoglycan and novel poly(erythritol phosphate) teichoic acids in cell walls of two coryneform isolates from the surface flora of French cooked cheeses. Arch. Microbiol. 160:222-228.

25. Seiler, H., R. Braatz, and G. Ohmayer. 1980. Numerical cluster analysis of the coryneform bacteria from activated sludge. Zentralbl. Bakteriol. Parasitenkd. Infektionskr. Hyg. Abt. 1 Orig. Reihe C 1:357-375.

26. Springer, N., W. Ludwig, R. Amann, H. J. Schmidt, H. D. Görtz, and K. H. Schleifer. 1993. Occurrence of fragmented 16S rRNA in an obligate bacterial endosymbiont of Paramecium caudatum. Proc. Natl. Acad. Sci. USA 90: 9892-9895.

27. Stackebrandt, E., and B. M. Goebel. 1994. Taxonomic note: a place for DNA-DNA reassociation and 16S rRNA sequence analysis in the present species definition in bacteriology. Int. J. Syst. Bacteriol. 44:846-849.

28. Strunk O. (Technische Universität München). 1995. Personal communication.

29. Takeuchi, M., C.-X. Fang, and A. Yokota. 1995. Taxonomic study of the genus Brachybacterium: proposal of Brachybacterium conglomeratum sp. nov., nom. rev., Brachybacterium paraconglomeratum sp. nov., and Brachybacterium rhamnosum sp. nov. Int. J. Syst. Bacteriol. 45:160-168. 